\title{
KONSEPSIE CHRISTELIK-NASIONAAL
}

In sy artikel soek dr. J.H. van Wyk na 'n omvattender en indringender plaasvervanger vir die begrip Christelik-Nasionaal. Dit doen hy deur:

* kritiek te lewer op die naam „Christelik-Nasionaal";

* in die plek daarvan voor te stel die uitdrukking: „Koninkryks-".

Sy artikel getuig van ernstige en oorspronklike denke. 'n Mens kan dan ook waardering hê vir sy bydrae in hierdie verband. Veral sy waarskuwing dat gewaak moet word teen 'n genasionaliseerde Christendom is beslis tydig en nodig.

Aan die ander kant kan daar egter ook kritiek uitgespreek word teen die gedagterigting wat in hierdie artikel ingeslaan word. Om slegs een voorbeeld te noem: As dr. Van Wyk in punt 3 van sy artikel voorstel dat byvoorbeeld CNO vervang moet word met „Koninkryksonderwys", kan onmiddellik gevra word: Waarom dan nie liewer „Verbondsonderwys" nie? Vir laasgenoemde konsepsie vind ons baie meer direkte en opvallende steun in die Heilige Skrif en veral ook in vraag 3 van ons doopsformulier (by kinderdoop).

Sonder om egter op besonderhede in te gaan, wil ek enkele redes aanvoer waarom ek meen dat ons dr. Van Wyk se gedagterigting moet afwys:

3.1 Hy laat Skriftuurlike gegewens buite rekening waarop die term „Christelik" steun

3.1.1 In Hand. 11:26 (en 1 Petr. 4:16) word Christus se volgelinge „Christene" genoem. Hulle word na hul Verlosser se ampsnaam Christus genoem, omdat hulle as gesalfdes (in Christus) 'n taak, 'n amp, 'n diens het om te vervul in hierdie wêreld. (Vergelyk Heidelbergse Kategismus, vraag 32.) Dié naam sê: Hulle staan nie slegs in diens van Christus die Koning nie, maar ook in diens van Christus die Priester en Christus die Profeet. Die werk wat Christene doen, kan dan goedskiks aangedui word met die term: Christelik. Die uitdrukking Christelik is so omvattend as wat moontlik is om die taak en roeping van God se kinders op aarde aan te dui - hul taak op die terrein van die kerk, die skool, die politiek of watter terrein ook al. Daarom is dit ook Skriftuurlik-logies om te praat van die Christelike kerk. 'n Christelike politieke party of byvoorbeeld Christelike onderwys. Dat daar in som. 
mige gevalle nog ,nasionaal" bygevoeg word, (byvoorbeeld CNO) is histories te verklaar, en in elk geval ook nie onskriftuurlik nie.

3.1.2 Matt. $28: 18$ en 1 Kor. $15: 22-28$ is myns insiens van groot betekenis in verband met die saak wat $\mathrm{dr}$. Van Wyk behandel.

In Matt. 28:18 sê Christus: „Aan My is gegee alle mag in die hemel en op die aarde."

In hierdie bedeling is die koningskap heel bepaald in die hande van Christus, en nie maar vaagweg in die hande van die Drie-enige God nie. Wie dus van die Koninkryk praat, praat van Christus die Koning. Die term "Christelik" is slegs duideliker as die term „Koninkryks-", omdat dit sê van watter koninkryk jy praat.

I. Kor. 15:22-28 trek die lyn van Matt. 28:18 af deur na die wederkoms: „Daarna kom die einde, wanneer Hy die koninkryk aan God die Vader oorgee..." (vers 24) en:

"En wanneer alles aan Hom onderwerp is, dan sal ook die Seun Self Hom onderwerp aan die Een wat alles aan Hom onderwerp het, sodat God alles in almal kan wees" (vers 28).

Ons beleef dus nou die tyd (tussen hemelvaart en wederkoms) waarin Christus op die voorgrond is sover dit die koninkrykswerk van God Drieenig betref. In hierdie bedeling kan die aktiwiteite en die instellings van mense slegs onder een van twee kategorieë ingedeel word: òf vir Christus (dus Christelik); òf teen Christus (dus antichristelik).

Die term ,Koninkryks-" sê nie vir almal duidelik aan watter kant jy staan nie. Ons het in die praktyk tog te doen met die koninkryk van God aan die een kant en die koninkryk van die duisternis aan die ander kant. In hierdie wêreld gaan dit in die onderwys, die politiek, die ekonomie, die kuns of wat ook al, om die vraag of jy vir Christus (Christelik) of teen Hom (onchristelik, antichristelik) is.

3.2 Wat die byvoeging "nasionale" betref, laat dr. Van Wyk in sy kritiek nie reg geskied aan die invloed van die geskiedenis in verband met die totstandkoming van die uitdrukking "Christelik-nasionaal" nie. Dit geld veral CNO.

CNO het tog ontstaan as teëvoeter vir die neutrale en antinasionale onderwys in ons land:

* neturaal, sonder die Bybel, reeds al vanaf 1804 ;

* en anti-nasionaal, vanaf kort na 1806, en veral vanaf 1902.

Dic CNO-skole is Christelik genoem, teenoor die neutrale skole. Dit is nasionaal genoem, teenoor die antinasionale gees van dic liberalisme wat die 
mensdom sien as 'n konglommeraat van individue en nie as organie: :aamgestel uit volke nie. Die onderwys in sodanige skole is dus Christelik-nasionaci genoem, omdat die onderrig van die Bybel en die geskiedenis in die eie cial op die voorgrond moes staan. Die vak geskiedenis bring 'n mens ook uit by jou eie volk en jou eie taal. Geskiedenis (wat tog niks anders is as die realisering van God se raad met die volke nie) sê ook vir jou wie jy is.

Die geringskatting van die nasionale kom nie uit die Skrif nie. Professore W.J. Snyman en J.C. Coetzee het dit myns insiens in hul studies in hierdie verband duidelik genoeg aangetoon.

Om slegs een voorbeeld uit die Skrif te noem: Paulus is as gelowige nie skaam om sy volksverband aan te dui met die woorde: ,Ek is ook 'n Israeliet" nie (Rom. 11:1). Toe hy Christen geword het, het hy nie skielik ver ander van 'n Israeliet in 'n kosmopoliet of 'n wêreldburger nie.

As ons as Christene dan ook praat van $\mathrm{CN}$-onderwys en $\mathrm{CN}$-politiek, dan bly ons met hierdie terme nie alleen in die historiese lyn as gelowige Afrikaners nie, maar ons bly ook in lyn met die Heilige Skrif.

Die Christelike moet natuurlik vir ons as gelowiges die nasionale bepaal. Daarom kom daar juis uit die benaming 'n gedurige roepstem tot reformasie. Ook in die lewe van 'n volk gaan dit ten slotte of vir Christus (dan Christelik-nasionaal) of teen Christus (dan onchristelike of anti-Christelike nasionalisme).

Ek wil hierdie beknopte diskussie afsluit deur dit as my oortuiging te stel dat ons, teenoor dr. Van Wyk se poging, juis nie moet soek na 'n omvattende en oorkoepelende begrip waarmee ons alle moontlike instellinge en aksies probeer dek nie. Selfs wat die begrip Christelik-nasionaal betref, kan myns insiens in baie gevalle volstaan word met die benaming "Christelike", sonder die byvoeging van die "nasionale". Dit was trouens die geval in die verlede. Die begrip $\mathrm{CN}$ is hoofsaaklik gebruik ten opsigte van die onderwys, en daarvoor was daar duidelik historiese aanleiding.

Ons moet nie alles in die keurslyf van 'n omvattende konsepsie wil dwing nie. Daarvoor is sowel God se algemene as sy besondere openbaring te soepel en te ryk in verskeidenheid. Omstandighede en die ty.dgees wissel ook te veel van tyd tot tyd. Juis die soeke na "'n omvattender en indringender konsepsie" kan ons in nuwe slaggate van denkedwang laat beland. 